\title{
PENGARUH TRANSPARANSI DAN AKUNTABILITAS KEUANGAN SEKOLAH TERHADAP MOTIVASI MENGAJAR GURU DI KABUPATEN KEEROM
}

\author{
Penulis: \\ Juliana Tandililing ${ }^{1}$ \\ tandililing.anna@gmail.com
}

\begin{abstract}
The purpose of this study was to analyze the effect of transparency and accountability in school finances with teacher teaching motivation. This study was conducted in Keerom Regency, one of the districts in the Indonesia - Papua New Guinea border region. This research is an empirical study that examines the direct relationship of variables. The population numbered 1,129 teachers, with a sample of 200 people. The results of the study explain the variables of transparency and financial accountability together to influence the teaching motivation of teachers. Partial test results show the effect of transparency is significant, but the effect of accountability is apparently not significant.
\end{abstract}

Keywords: Transparansi, Akuntabilitas dan Motivasi Mengajar

\section{PENDAHULUAN}

Sistem Pendidikan Nasional yang diatur Undang-Undang No. 20 tahun 2003 menjelaskan bahwa kewajiban tenaga pendidik atau guru adalah mempunyai komitmen secara profesional untuk meningkatkan mutu pendidikan. Undang-Undang No. 20 tahun 2003 Pasal 48 meletakkan prinsip pengelolaan dana pendidikan yang berdasarkan prinsip partispasi, transparansi, akuntabilitas publik, efisiensi, dan keadilan.

Dengan demikian, guru memiliki tugas dan tanggung jawab yang besar untuk mencerdaskan kehidupan bangsa, karena seorang guru pada akhirnya dituntut memiliki kompetensi yang dapat mendukung minat belajar dan hasil belajar siswa. Guru dapat dilihat dari proses pembelajaran, mengingat proses pembelajaran merupakan inti dari proses pendidikan. Undang-undang No.14 Tahun 2005 tentang Guru dan Dosen, adalah pendidik profesional dengan tugas utama pendidik,mengajar,membimbing, mengarahkan, melatih, menilai, dan mengevaluasi

1 Dinas Pendidikan Kabupaten Keerom 
peserta didik pada pendidikan anak usia dini jalur pendidikan formal, pendidikan dasar, dan pendidikan menengah secara jelas telah menyatakan bahwa dalam melaksanakan tugas keprofesionalannya, guru berkewajiban melaksanakan proses pembelajaran yang bermutu, serta meningkatkan dan mengembangkan kualifikasi akademik dan kompetensi secara berkelanjutan. Undang-undang RI No.14 Tahun 2005.

Dalam undang-undang tentang keuangan Negara, terdapat penegasan di bidang pengelolaan keuangan, yaitu : kekuasaan pengelolaan keuangan negara merupakan bagian dari kekuasaan pemerintahan dan kekuasaan pengelolaan keuangan negara dari presiden sebagian diserahkan kepada gubernur/bupati/walikota selaku kepala pemerintahan daerah untuk mengelola keuangan daerah dan mewakili pemerintah daerah dalam kepemilikan kekayaan daerah yang dipisahkan. Ketentuan tersebut berimplikasi pada pengaturan pengelolaan keuangan daerah, yaitu bahwa gubernur/bupati/walikota bertanggung jawab atas pengelolaan keuangan daerah sebagai bagian dari kekuasaan pemerintah daerah. Dengan demikian, pengaturan pengelolaan keuangan dan pertanggungjawaban keuangan daerah melekat dan menjadi satu dengan pengaturan keuangan pemerintah daerah, hal tersebut tercantum dalam UU mengenai pemerintah daerah.

Shafratunnisa (2015) Motivasi adalah proses yang menjelaskan instensitas, arah, dan ketekunan seorang individu atau guru dalam mengajar sehingga tercapai suatu tujuan, motivasi dapat memacu seseorang untuk bekerja keras sehingga suatu tujuan dapat tercapai. Motivasi mengajar seorang guru merupakan pengukuran yang dapat dilakukan sendiri atau bekerja-sama dengan kepala sekolah dan pelaksana pemeriksaan. Pengukuran kinerja sangat penting bagi sekolah yang berorientasikan hasil untuk mengukur kinerjanya sendiri dan melihat tingkat kinerja yang telah dicapai atau hasil-hasil yang diperoleh. Kinerja dapat dilakukan dengan baik jika ada satuan 
pengukuran kinerja yang sahih. Cara-cara pengukuran yang tepat sangat tergantung pada sistem informasi yang ada untuk pengumpulan data yang tepat dan akurat.

Dalam hal ini, tuntutan akuntabilitas publik mengharuskan penekanannya pada pertanggungjawaban horizontal bukan hanya pertanggungjawaban vertikal. Akuntabilitas publik yang harus dilakukan oleh organisasi sektor public terdiri atas berbagai dimensi. Ellwood dalam Mahsun (2006) menjelaskan terdapat empat dimensi akuntabilitas yang harus dipenuhi olehorganisasi sector publik, yaitu akuntabilitas kejujuran dan akuntabilitas hukum, akuntabilitas proses, akuntabilitas. program, dan akuntabilitas kebijakan. Akuntabilitas tidak saja menyangkut proses, kinerja dan manajemen, akan tetapi juga menyangkut pengelolaan keuangan, dan kualitas output. Akuntabilitas keuangan dapat diukur dari semakin kecilnya penyimpangan dalam pengelolaan keuangan sekolah. Pengelola keuangan yang bertanggung jawab akan mendapat kepercayaan dari warga sekolah dan orang tua murid, Boy (2009).

Menurut Chung \& Megginson dalam Gomes (2001:177) menjelaskan "motivation is defined as goal-directed behavior. It concerns the level of effort one exerts in pursuing a goal it is closely related to employee atisfaction and job performance" (motivasi dirumuskan sebagai perilaku yang ditujukan pada sasaran motivasi berkaitan dengan tingkat usaha yang dilakukan oleh seseorang dalam mengejar suatu tujuan, motivasi berkaitan erat dengan kepuasan pekerjaan dan performansi pekerjaan). Motivasi merupakan sikap atau tingkah laku sekelompok orang untuk bekerja sama dengan giat dan konsekuensi dalam mencapai tujuan dengan penuh tanggungjawab dan disiplin ,sehingga pekerjaan dapat terlaksana dengan mudah ,dapat tercapai apa yang menjadi tujuannya Engkay Karweti (2010)

Sering terjadi permasalahan dalam pelaksanaan keuangan sekolah yang pada umumnya masih kurangnya transparansi dan akuntabilitas dalam pengelolaan keuangan sekolah yaitu Dana Alokasi Khusus (DAK), Dana Alokasi Umum (DAU), 
$\mathrm{DBH}, \mathrm{PAD}$, dana BOS, dan dana Otsus padahal penggunaan dana keuangan sekolah tersebut mestinya melibatkan guru dan orangtua siswa, perencanaan maupun pada pelaporan keuangan sekolah sebagian besar orangtua siswa pernah mendengar adanya program keuangan Sekolah. Namun, masih sangat sedikit orangtua yang mengetahui informasi yang lebih rinci tentang dana Keuangan Sekolah, bahkan dana sekolah lainnya terutama menyangkut jumlah Dana keuangan Sekolah, sehingga dikhawatirkan pengelolaandana dana keuangan sekolah tidak sesuai dengan alokasi penggunaan dana yang dimaksud oleh pemerintah.

Pemimpin dalam suatu sekolah adalah kepala sekolah. yang merupakan top manager dan harus memiliki kompetensi yang baik. Dinas Pendidikan dan Pengajaran Kabupaten Keerom adalah salah satu SKPD yang mengurus bidang pendidikan, dalam menjalankan tugasnya berpedoman pada Peraturan Bupati Keerom Nomor 12 Tahun 2008 tentang Rincian Tugas dan Fungsi Dinas Pendidikan dan kebudayaan Kabupaten Keerom. Jumlah Penduduk Kabupaten Keerom sebagaimana dirilis oleh BPS Kabupaten Keerom dalam bukunya " Keerom Dalam Angka 2015" tercatat sebanyak 53.002 jiwa, yang terdiri dari 28.82 orang penduduk laki-laki $(53,82 \%)$ dan 24.176 orang penduduk perempuan $(46,18 \%)$. Pelayanan pendidikan merupakan hal yang sangat penting dalam peningkatan kualitas pendidikan, peningkatan kualitas tenaga pendidik dan tenaga kependidikan, serta manajemen pelayanan pendidikan yang berkualitas baik dan juga bagi masyarakat. Salah satu dari kebutuhan pokok manusia adalah terwujudnya keadaan pendidikan yang adil dan merata.

Fenomena yang sering terjadi dalam sistem transparansi dan akuntabilitas keuangan sekolah terhadap motivasi mengajar guru. Dapat dilihat dari sejumlah guru, komite sekolah dan orang tua siswa, adanya ketidak jelasan dana - dana sekolah kurang yang penggunaannya tidak jelas dan kurang lancar bahkan tidak transparan. Kepala sekolah dianggap menutup informasi bukan saja kepada guru bahkan kepada 
orangtua murid. Lahirnya rasa saling tidak percaya tentunya akan berdampak buruk bahkan cenderung pada kecurigaan dan penyalagunaan dana, kecurigaan pada alokasi dan penggunaan dana yang tidak sesuai dengan aturan dan tidak tepat sasaran. Fakta lain yang menyangkut akuntabilitas yaitu pemberian dana yang tidak diikuti dengan prinsip akuntabilitas pelaporan dan laporan penggunaan dana dari semua tingkat, Sekolah Dasar dan Sekolah Menengah Pertama.

Studi ini merumuskan dua tujuan, yaitu gambaran transparansi, akuntablitas keuangan sekolah, dan motivasi mengajar guru; dan hubungan atau pengaruh transparansi dan akuntabalitas keuangan terhadap motivasi mengajar guru.

\section{TINJAUAN PUSTAKA}

\section{Motivasi Mengajar Guru}

Motivasi dapat diartikan sebagai keadaan dalam diri pribadi seseorang sehingga orang tersebut terdorong untuk melakukan suatu kegiatan atau aktivitas. Oleh karena itu, motivasi mempunyai sifat yang tidak lepas dari sifat manusia itu sendiri, dimana manusia secara individual mempunyai kualitas eksistensi diri yang berbeda satu dengan yang lainnya, Slamet Riyadi (2011). Kenyataan yang terjadi selama ini adalah semakin sulit menemukan guru dengan motivasi yang tinggi dalam dirinya, sejalan dengan perkembangan zaman, motivasi guru.

Kenyataan yang terjadi selama ini adalah semakin sulit menemukan guru dengan motivasi yang tinggi di dalam dirinya. Sejalan dengan perkembangan zaman, motivasi guru dalam berkarya tidak lagi motivasi yang muncul dari dalam dirinya melainkan motivasi yang berasal dari luar dirinya, seperti: gaji dan insentif. Motivasi belajar adalah kecenderungan siswa dalam melakukan kegiatan belajar yang didorong oleh hasrat untuk mencapai prestasi atau hasil belajar sebaik mungkin "Motivasi" sering diartikan dengan istilah dorongan. Motivasi adalah alasan yang didasari sebuah perbuatan yang dilakukan oleh seorang individu 
Guru menempati posisi yang strategis dan kunci dalam proses belajar mengajar dan guru harus mampu memberi bantuan kepada siswa dalam memperoleh pengetahuan maupun keterampilan sesuai tujuan pendidikan. Fasilitator dan informasi yang sangat diperlukan oleh siswa ada pada guru karena guru berperan besar dalam membina siswa sehingga memiliki mental dan intelektual yang baik. Prinsip mengajar adalah mempermudah dan memberikan motivasi kegiatan belajar ,sehingga guru sebagai pengajar memiliki tugas memberikan fasilitas atau kemudahan bagi suatu kegiatan belajar subjek belajar/ siswa, Yuliyani (2010).

Motivasi merupakan suatu dorongan yang menyebabkan anak didik melakukan sesuatu perubahan energi untuk menciptakan kondisi atau sistem lingkungan yang mendukung dan memungkinkan untuk berlangsungnya proses belajar. Dan mengajar adalah menyampaikan pengetahuan kepada anak didik. Menurut Tabrani (1989) dalam Rohani (2008) motivasi mengajar guru mencakup empat dimensi yaitu; 1) motivasi guru dalam membuat perencanaan pengajaran, 2) motivasi guru dalam melakukan proses pengajaran, 3) motivasi guru dalam melakukan penilaian pengajaran, 4) motivasi guru dalam meningkatkan prestasi belajar peserta didik. Dalam pendidikan perlu dikembangkan strategi-strategi yang tepat untuk mendayagunakan peluang yang dibuka oleh pemerintah dengan kebijakan desentralisasi dan otonomi yang sudah digulirkan.

\section{Transparansi}

Krina (2003:13) mendefinisikan transparansi sebagai prinsip yang menjamin akses atau kebebasan bagi setiap orang untuk memperoleh informasi tentang penyelenggaraan pemerintahan, yakni informasi tentang kebijakan proses pembuatan dan pelaksanaanya serta hasil - hasil yang dicapai.

Transparansi adalah adanya kebijakan terbuka bagi pengawasan. Sedangkan yang dimaksud dengan informasi adalah informasi mengenai setiap aspek kebijakan 
pemerintah yang dapat dijangkau publik. Keterbukaan informasi diharapkan akan menghasilkan persaingan politik yang sehat, toleran, dan kebijakan dibuat beradsarkan preferensi public.

Menurut Mardiasmo (2004:30), transparansi berarti keterbukaan (opennsess) pemerintah dalam memberikan informasi yang terkait dengan aktivitas pengelolaan seumber daya publik kepada pihak - pihak yang membutuhkan informasi.

Menurut Sabarno (2007:38), transparansi merupakan salah satu aspek mendasar bagi terwujudnya penyelenggaraan pemerintahan yang baik. Perwujudan tata pemerintahan yang baik mensyaratkan adanya keterbukaan, keterlibatan, dan kemudahan akses bagi masyarakat terhadap proses penyelenggaraan pemerintah. Keterbukaan dan kemudahan informasi penyelenggaran pemerintahan memberikan pengaruh untuk mewujudkan berbagai indikator lainnya.

Dwiyanto (2006:80) mendefinisikan transparansi sebagai penyediaan informasi tentang pemerintahan bagi publik dan dijaminnya kemudahan di dalam memperoleh informasi-informasi yang akurat dan memadai. Dari pengertian tersebut dijelaskan bahwa transparansi tidak hanya sekedar menyediakan informasi tentang penyelenggaraan pemerintahan, namun harus disertai dengan kemudahan bagi masyarakat untuk memperoleh informasi tersebut.

Dengan melihat uraian di atas, prinsip transparansi pemerintahan paling tidak dapat diukur melalui sejumlah indikator sebagai berikut:

a. Adanya sistem keterbukaan dan standarisasi yang jelas dan mudah dipahami dari semua proses-proses penyelenggaraan pemerintahan.

b. Adanya mekanisme yang memfasilitasi pertanyaan-pertanyaan publik tentang proses-proses dalam penyelenggaraan pemerintahan.

c. Adanya mekanisme pelaporan maupun penyebaran informasi penyimpangan tindakan aparat publik di dalam kegiatan penyelenggaraan pemerintahan. 
Berdasarkan uraian tersebut dapat disimpulkan bahwa prinsip transparansi meliputi; a) keterbukaan, b) standarisasi, c) mekanisme publik, dan d) pelaporan.

\section{Akuntabilitas Keuangan}

Akuntabilitas merupakan istilah yang berasal dari kata account yang berarti catatan atau laporan dan ability yang berarti kemampuan. Akuntabilas (accountability) secara umum dapat diartikan suatu bentuk pertanggung jawaban. Organisasi yang accountable adalah organisasi yang mampu menyajikan informasi secara terbuka mengenai keputusan-keputusan yang telah diambil dan memungkinkan pihak luar mereview inforamsi tersebut, serta bila dibutuhkan harus ada kesediaan untuk mengambil tindakan kreatif Sutama (2006).

Akuntabilitas adalah kewajiban untuk memberikan pertanggungjawaban atau untuk menjawab dan menerangkan kinerja dan tindakan penyelenggara organisasi kepada pihak yang memiliki hak atau berkewenangan untuk meminta keterangan atau pertanggjawaban. Cara menyebarluaskan informasi dalam hal: (a) pembuatan dan pelaksanaan kebijakan serta perencanaan, (b) anggaran pendapatan dan belanja sekolah, (c) pengelolaan sumberdaya pendidikan di sekolah, dan (d) keberhasilan atau kegagalan pelaksanaan rencana sekolah dalam mencapai tujuan dan sasaran yang telah ditetapkan, Depdiknas (2009).

Tujuan utama akuntabilitas adalah untuk mendorong terciptanya akuntabilitas kinerja sekolah sebagai salah satu prasyarat untuk terciptanya sekolah yang baik dan terpercaya. Akuntabilitas bertujuan untuk menciptakan kepercayaan publik terhadap sekolah. Pengelolaan manajemen sekolah yang baik akan berdampak pada kepercayaan publik yang baik pula. Dengan demikian dapat dikatakan bahwa terciptanya kepercayaan publik selalu berbanding lurus dengan apa yang telah dilakukan oleh sekolah. Selain itu tujuan akuntabilitas adalah untuk menilai kinerja sekolah dan kepuasan publik terhadap pelayanan pendidikan yang diselenggarakan oleh sekolah, untuk mengikut sertakan publik dalam pengawasan pelayanan pendidikan, dan untuk mempertanggung jawabkan komitmen pelayanan pendidikan kepada publik Surya Dharma (2010).

Keberhasilan akuntabilitas dapat diukur dengan beberapa indikator berikut, yaitu: (a) meningkatnya kepercayaan dan kepuasan publik terhadap sekolah, (b) tumbuhnya 
kesadaran publik tentang hak untuk menilai terhadap penyelenggaraan pendidikan di sekolah, (c) berkurangnya kasus-kasus KKN di sekolah, dan (d) meningkatnya kesesuaian kegiatan-kegiatan sekolah dengan nilai dan norma yang berkembang di masyarakat.

\section{METODE PENELITIAN}

Penelitian ini adalah penelitian kuantitatif adalah suatu proses menemukan pengetahuan yang menggunakan data berupa angka sebagai alat menganalisis keterangan mengenai apa yang ingin diketahui. Penelitian ini termasuk penelitian expost-facto yang bersifat korelasional dengan meneliti pengaruh langsung maupun pengaruh tak langsung variable bebas terhadap variable takbebas.

Penelitian ini menggunakan analisis deskriftif dan analisis inferensial. Analisis deskriptif dimaksudkan untuk mengambarkan distribusi jawaban responden guru, dengan menggunakan tabel distribusi frekuensi dan persentase. Analisis menggunakan regresi berganda, yang dimaksudkan untuk menguji hubungan atau pengaruh variabel transparansi dan akuntabilitas terhadap motivasi mengajar guru. Persamaan regresi yang digunakan adalah:

$$
Y^{\prime}=a+b_{1} \cdot X_{1}+b_{2} \cdot X_{2}+e
$$

Dimana:

$\mathrm{Y} \quad$ : Motivasi mengajar

X1 : Transparansi keuangan

X2 : Akuntabilitas keuangan

Data-data yang diperlukan dalam penelitian ini diperoleh dengan instrument penelitian denga menggunakan angket atau kuesioner. Penelitian ini menggunakan tiga instrumen dengan model skala likert. Skala tersebut disusun sendiri mengikuti model Likert dan mengacu pada teori yang dikemukakan oleh Claife (dalam Syah (1995). Skala ini disajikan dalam bentuk pernyataan positif dan negatif, Penyekoran 
skala ini didasarkan pada pilihan tanggapan subjek terhadap 1 jawaban dari 5 pilihan yang disediakan untuk tiap pernyataan, yaitu: sangat sesuai (SS), sesuai (S), cukup sesuai (CS), kurang sesuai (KS), dan tidak sesuai (TS). Untuk item positif penilaian pilihan jawaban sangat sesuai $(S S)=5$, sesuai $(S)=4$, cukup sesuai $(C S)=3$, kurang sesuai $(\mathrm{KS})=2$, dan tidak sesuai $(\mathrm{TS})=1$. Sedangkan untuk item negatif pilihan jawaban sangat sesuai $(S S)=1$, sesuai $(S)=2$, cukup sesuai $(C S)=3$, kurang sesuai $(\mathrm{KS})=4$, dan tidak sesuai $(\mathrm{TS})=5$. Teknik skoring untuk pernyataan unfavorable, dilakukan secara terbalik.

Populasi dalam penelitian ini adalah seluruh guru SD dan SMP sederajat yang ada di Kabupaten Keerom yang berjumlah 1129 orang guru, termasuk Kepala Sekolah dan guru tidak tetap (GTT). Teknik penarikan sampel penelitian ini menggunakan teknik stratified random sampling, berjumlah 200 orang.

\section{HASIL PENELITIAN}

Gambaran transparansi keuangan sekolah di Kabupaten Keerom dapat dilihat pada tabel 4.1 berikut ini.

Tabel 4.1 Distribusi data transparansi keuangan sekolah di Kabupaten Keerom

\begin{tabular}{clcc}
\hline \multirow{2}{*}{ Interval } & Transparansi & & \\
\cline { 3 - 4 } & Keuangan & $\mathrm{F}$ & $\%$ \\
\hline $68-80$ & Sangat tinggi & 82 & 41 \\
$55-67$ & Tinggi & 97 & 48,5 \\
$42-54$ & Sedang & 21 & 10,5 \\
$29-41$ & Rendah & 0 & 0 \\
$16-28$ & Sangat rendah & 0 & 0 \\
\hline & Jumlah & 200 & 100 \\
\hline
\end{tabular}

Sumber: Data Hasi Penelitian (2019)

Gambaran mengenai akuntablitas keuangan sekolah di Kabupaten Keerom dapat dilihat pada tabel 4.2 berikut ini.

Tabel 4.2 Distribusi data akuntablitas keuangan sekolah di Kabupaten Keerom

\begin{tabular}{cccc}
\hline \multirow{2}{*}{ Interval } & $\begin{array}{c}\text { Akuntabilitas } \\
\text { Keuangan }\end{array}$ & $\mathrm{F}$ & $\%$ \\
\hline
\end{tabular}




\begin{tabular}{llcc}
\hline $63-75$ & Sangat tinggi & 22 & 11 \\
$51-62$ & Tinggi & 75 & 37,5 \\
$39-50$ & Sedang & 95 & 47,5 \\
$27-38$ & Rendah & 8 & 4 \\
$15-26$ & Sangat rendah & 0 & 0 \\
\hline & Jumlah & 200 & 100 \\
\hline
\end{tabular}

Sumber: Data Hasi Penelitian (2019)

Gambaran motivasi mengajar guru di Kabupaten Keerom dapat dilihat pada tabel 4.3 berikut ini.

Tabel 4.3 Distribusi data motivasi mengajar guru di Kabupaten Keerom

\begin{tabular}{clcc}
\hline \multirow{2}{*}{ Interval } & Motivasi mengajar & & \\
\cline { 3 - 4 } guru & $\mathrm{F}$ & $\%$ \\
\hline $63-75$ & Sangat tinggi & 59 & 29,5 \\
$51-62$ & Tinggi & 125 & 62,5 \\
$39-50$ & Sedang & 16 & 8 \\
$27-38$ & Rendah & 0 & 0 \\
$15-26$ & Sangat rendah & 0 & 0 \\
\hline & Jumlah & 200 & 100
\end{tabular}

Sumber: Data Hasi Penelitian (2019)

Uji Hipotesis

Hipotesis yang diajukan adalah "Terdapat pengaruh transparansi keuangan sekolah dan akuntablitas keuangan sekolah terhadap motivasi mengajar guru di Kabupaten Keerom" dengan kata lain diduga bahwa semakin tinggi transparansi keuangan sekolah dan akuntabiltas keuangan sekolah maka semakin tinggi pula motivasi mengajar guru. Sebaliknya semakin rendah transparansi keuangan sekolah, dan akuntabilitas keuangan sekolah maka semakin rendah pula motivasi mengajar guru.

Secara statistik, hipotesis di atas dapat dirumuskan sebagai berikut Tolak Ho jika t hitung $>\mathrm{t}$ tabel dan atau Terima Ho jika t hitung $<\mathrm{t}$ tabel dan nilai signifikasi $\alpha<$ 0.05. uji hipotesis penelitian ini dapat dijabarkan sebagai berikut:

Untuk melihat data hasil uji regresi pada penelitian ini dapat dilihat pada tabel 4.6 berikut:

Tabel 4.6 Coefficients ${ }^{a}$ 


\begin{tabular}{|c|c|c|c|c|c|c|}
\hline \multirow{2}{*}{\multicolumn{2}{|c|}{ Model }} & \multicolumn{2}{|c|}{$\begin{array}{c}\text { Unstandardized } \\
\text { Coefficients }\end{array}$} & \multirow{2}{*}{$\begin{array}{c}\text { Standardized } \\
\text { Coefficients } \\
\text { Beta }\end{array}$} & \multirow[b]{2}{*}{$\mathrm{t}$} & \multirow[b]{2}{*}{ Sig. } \\
\hline & & B & Std. Error & & & \\
\hline \multirow[t]{3}{*}{1} & (Constant) & 43.024 & 4.329 & & 9.938 & .000 \\
\hline & Transparansi & .178 & .067 & .194 & 2.666 & .008 \\
\hline & Akuntabilitas & .101 & .055 & .135 & 1.845 & .066 \\
\hline
\end{tabular}

a. Dependent Variable: Motivasi Guru

Sumber: Data hasil Uji Hipotesis

Dari tabel 4.6 diperoleh nilai komponen $\mathrm{a}=43.024$ dan nilai komponen $\mathrm{b} 1=$ 0.178 dan nilai komponen b2 $=0.101$. Nilai a merupakan besarnya nilai variabel $Y$ apabila nilai $\mathrm{X} 1$ dan $\mathrm{X} 2=0$, sedangkan nilai $\mathrm{b}$ adalah nilai koofisien regresi $\mathrm{Y}$ atas $\mathrm{X} 1$ dan X2.

Berdasarkan hasil dari perhitungan regresi ganda maka diperoleh nilai persamaan regresi sebagaimana dirangkum pada tabel 4.7. Hal tersebut menunjukkan hubungan variabel Transparansi (X1) dan variabel Akuntabilitas (X2) dengan Motivasi Belajar Guru $(Y)$. Konstanta pada kolom B $=43.024$, variabel Transparansi $(X 1)=$ 0.178 dan variabel Akuntabilitas $(\mathrm{X} 2)=0.101$

Tabel 4.7 Persamaan Regresi Transparansi (X1) dan Akuntabilitas (X2) dengan Motivasi Belajar Guru (Y)

\begin{tabular}{ccc}
\hline $\mathrm{a}$ & 43.024 & Persamaan Regresi Ganda \\
\hline $\mathrm{b} 1$ & 0.178 & $\mathrm{Y}^{\prime}=43.024+0.178 . \mathrm{X}_{1}+0.101 \mathrm{X}_{2}$ \\
\hline $\mathrm{b} 2$ & 0.101 & \\
\hline
\end{tabular}

Sumber: Data hasil uji hipotesis

Selanjutnya untuk mengetahui signifikansi dilakukan dengan nilai $\mathrm{F}$ pendekatan analisis model Anova. Uji F ini bertujuan melihat signifikansi atau arah nyata pada taraf kepercayaan 95\%. Kriteria probabilitas nilai $\mathrm{F}$ adalah, Fhitung $>$ Ftabel dengan derajat kebebasan tertentu. Hal tersebut dapat dilihat pada tabel 4.8 berikut:

Tabel 4.8 ANOVA $^{a}$

\begin{tabular}{|c|c|c|c|c|c|c|}
\hline Model & & $\begin{array}{l}\text { Sum of } \\
\text { Squares }\end{array}$ & df & $\begin{array}{l}\text { Mean } \\
\text { Square }\end{array}$ & $\mathrm{F}$ & Sig. \\
\hline \multirow{3}{*}{1} & Regression & 697.665 & 2 & 348.832 & 7.854 & $.001^{\mathrm{b}}$ \\
\hline & Residual & 8749.210 & 197 & 44.412 & & \\
\hline & Total & 9446.875 & 199 & & & \\
\hline
\end{tabular}

a. Dependent Variable: MotivasiGuru 
b. Predictors: (Constant), Akuntabilitas, Transparansi

Sumber: Hasil Uji Hipotesis

Berdasarkan hasil perhitungan uji signifikan diperoleh nilai Fhitung $7.854>$ Ftabel 3.89. maka dapat disimpulkan bahwa regresi hubungan regresi Transparansi (X1) dan Akuntabilitas (X2) dengan Motivasi Belajar Guru (Y) signifikan.

Berdasarkan hasil analisis regresi linear berganda antara data transparansi keuangan sekolah (variabel independen) dan akuntabilitas keuangan sekolah (variable independen) dengan motivasi mengajar guru (variabel dependen) diketahui bahwa nilai signifikansi pengaruh transparansi keuangan sekolah dan akuntabilitas keuangan sekolah terhadap motivasi mengajar guru adalah $0.001<0.05$, sehingga Ho dinyatakan ditolak dan $\mathrm{Hi}$ dinyatakan diterima, sehingga dapat disimpulkan bahwa terdapat pengaruh transparansi keuangan sekolah dan akuntablitas keuangan sekolah terhadap motivasi mengajar guru di Kabupaten Keerom.

\section{PEMBAHASAN}

Berdasarkan analisis data pada hasil penelitian mengenai gambaran transparansi keuangan, akuntabilitas keuangan sekolah dan motivasi mengajar guru, pengaruh transparansi keuangan terhadap motivasi mengajar guru, pengaruh akuntabilitas keuangan sekolah terhadap motivasi mengajar guru, dan pengaruh transparansi keuangan serta akuntabilitas keuangan sekolah terhadap motivasi mengajar guru, maka selanjutnya diuraikan pembahasan hasil penelitian sebagai berikut:

\section{Transparansi keuangan sekolah}

Transparansi adalah adanya kebijakan terbuka bagi pengawasan. Sedangkan yang dimaksud dengan informasi adalah informasi mengenai setiap aspek kebijakan pemerintah yang dapat dijangkau publik. Keterbukaan informasi diharapkan akan menghasilkan persaingan politik yang sehat, toleran, dan kebijakan dibuat berdasarkan 
preferensi public.Berdasarkan hasil penelitian yang peneliti temukan dilapangan bahwa data transparansi keuangan sekolah di Kabupaten Keerom berada pada kategori tinggi.

\section{Akuntabilitas keuangan sekolah}

Akuntabilitas adalah kewajiban untuk memberikan pertanggungjawaban atau untuk menjawab dan menerangkan kinerja dan tindakan penyelenggara organisasi kepada pihak yang memiliki hak atau berkewenangan untuk meminta keterangan atau pertanggjawaban. Cara menyebarluaskan informasi dalam hal: (a) pembuatan dan pelaksanaan kebijakan serta perencanaan, (b) anggaran pendapatan dan belanja sekolah, (c) pengelolaan sumberdaya pendidikan di sekolah, dan (d) keberhasilan atau kegagalan pelaksanaan rencana sekolah dalam mencapai tujuan dan sasaran yang telah ditetapkan, Depdiknas (2009). Berdasarkan hasil penelitian yang peneliti temukan dilapangan bahwa data akuntablitas keuangan sekolah di Kabupaten Keerom berada pada kategori tinggi.

\section{Motivasi mengajar guru}

Motivasi dapat mendorong dan menggerakkan manusia dalam mencapai suatu tujuan. Karena untuk mencapai suatu keberhasilan seseorang tidak terlepas dari motivasi yang dimiliki. Akibat dari perasaan yang muncul dengan motivasi akan memberikan perubahan pada seseorang sehingga mendorong munculnya perasaan, jiwa maupun emosi sehingga untuk melakukan suatu tindakan yang disebabkan karena kebutuhan, keinginan dan tujuan. Secara etimologi motivasi berasal dari bahasa Inggris motivation yang memiliki kata dasar motif yang berarti tujuan atau segala upaya untuk mendorong seseorang dalam melakukan sesuatu. Untuk bergerak 
ke arah tujuan tertentu, baik itu disadari maupun tidak disadari, motivasi juga bisa menjadi suatu kekuatan, tenaga atau daya untuk dapat melakukan sesuatu. Berdasarkan hasil penelitian yang peneliti temukan dilapangan bahwa data motivasi mengajar guru di Kabupaten Keerom berada pada kategori tinggi.

\section{Pengaruh transparansi dan akuntabilitas terhadap motivasi mengajar guru}

Berdasarkan data hasil temuan di lokasi penelitian yang telah diolah dengan menggunakan analisis statistik inferensial telah ditemukan bahwa terdapat pengaruh transparansi keuangan sekolah terhadap motivasi mengajar guru di Kabupaten Keerom. Selanjutnya data hasil temuan di lokasi penelitian yang telah diolah dengan menggunakan analisis statistik inferensial telah ditemukan bahwa tidak ada pengaruh signifikan akuntablitas keuangan sekolah terhadap motivasi mengajar guru di Kabupaten Keerom. Selain itu, data hasil temuan di lokasi penelitian yang telah diolah dengan menggunakan analisis statistik inferensial telah ditemukan bahwa ada pengaruh secara bersama-sama transparansi keuangan sekolah dan akuntablitas keuangan sekolah terhadap motivasi mengajar guru di Kabupaten Keerom.

Transparansi keuangan sekolah dan akuntabilitas keuangan sekolah memberikan motivasi kerja bagi peningkatan produktivitas kerja guru dan hasil belajar siswa. Keuangan sekolah harus benar-benar dapat dipertanggungjawabkan, karena tanggung jawab kuangan sekolah sangat penting dan menentukan tinggi rendahnya hasil belajar para siswa, juga produktivitas dan semangat kerja guru tergantung pada transparansi dan akuntabilitas keuangan sekolah dalam arti sampai sejauh mana transparansi dan akuntabilitas keuangan sekolah mampu menciptakan kegairahan kerja dan sejauh mana mampu mendorong guru untuk bekerja sesuai dengan kebijaksanaan dan program yang telah digariskan sehingga produktivitas kerja guru tinggi dan hasil belajar siswa meningkat. 
Berdasarkan uraian uraian tiga point hasil penelitian di atas dapat disimpulkan bahwa ada pengaruh secara bersama-sama transparansi keuangan sekolah dan akuntablitas keuangan sekolah terhadap motivasi mengajar guru di Kabupaten Keerom. Secara parsial ada pengaruh signifikan transparansi keuangan sekolah terhadap motivasi mengajar guru di Kabupaten Keerom sedangkan akuntablitas keuangan sekolah tidak ada pengaruh signifikan terhadap motivasi mengajar guru di Kabupaten Keerom.

Hasil penelitian tersebut sejalan dengan penelitian yang dilakukan oleh Adlyana (2016) bahwa akuntabilitas, transparansi dan pengawasan secara simultan berpengaruh signifikan terhadap variable Kinerja Anggaran Berkonsep Value For Money Pada Satuan Kerja Perangkat Daerah Kabupaten Labuhanbatu Selatan. Secara parsial, transparansi dan pengawasan berpengaruh signifikan terhadap Kinerja Anggaran Berkonsep Value For Money Pada Satuan Kerja Perangkat Daerah Kabupaten Labuhanbatu Selatan, tetapi akuntabilitas tidak berpengaruh terhadap Kinerja Anggaran Berkonsep Value For Money Pada Satuan Kerja Perangkat Daerah Kabupaten Labuhanbatu Selatan.

Selain itu hasil temuan penelitian ini juga sejalan dengan penelitian yang dilaksanakan oleh Arifani, Salle, \& Rante (2018), bahwa 1) Akuntabilitas tidak berpengaruh terhadap kinerja anggaran berbasis value for money. Akuntabilitas merupakan salah satu unsur pokok yang terdapat pada perwujudan Good Corporate Governance. 2) Transparansi berpengaruh terhadap kinerja anggaran berbasis value for money dimana anggaran harus disajikan secara terbuka dan jelas mengenai tujuan, sasaran, hasil, dan manfaat yang diperoleh masyarakat dari suatu kegiatan atau proyek yang dianggarkan oleh pemerintah Kota Jayapura. 3) Pengawasan berpengaruh terhadap kinerja anggaran berbasis value for money, pengawasan itu sendiri merupakan sistem yang sangat penting yang diterapkan untuk mengawasi 
kegiatankegiatan manajerial yang dilakukan pada intsnasi pemerintah kota Jayapura dengan membandingkan pelaksaan yang telah dilakukan dan pelaksanaan yang direncanakan.

Selanjutnya Hasil penelitian ini sejalan dengan hasil temuan penelitian yang dilakukan oleh Utama dan Setiyani (2014) bahwa transparansi, akuntabilitas, dan responsibilitas pengelolaan keuangan sekolah berpengaruh secara simultan terhadap kinerja guru di SMP Negeri Eks-RSBI se-kota Semarang. Namun secara parsial hanya variabel responsibilitas pengelolaan keuangan sekolah yang memberikan kontribusi terhadap kinerja guru.

Lebih jauh hasil penelitian ini sesuai dengan hasil penelitian yang dilakukan oleh Andreana dan Wirajaya (2018) bahwa 1) Pengelolaan LPD yang transparan akan meningkatkan kinerja keuangan LPD. 2) Pengelolaan LPD dengan akuntabilitas yang baik akan meningkatkan kinerja keuangan LPD. 3) Pengelolaan LPD yang mematuhi peraturan serta perundang - undangan yang ada akan meningkatkan kinerja keuangan LPD. 4) Pengelolaan LPD yang independen tanpa campur tangan pihak lain dalam pengambilan keputusan LPD akan meningkatkan kinerja keuangan LPD. 5) Pengelolaan LPD yang memperlakukan stakeholder dengan adil dan setara akan membuat kinerja keuangan LPD mengalami peningkatan. Hal ini dapat ditunjukkan dengan semakin baik penerapan variabel transparancy, accountability, responsibility, independency, dan fairness dalam pengelolaan sebuah LPD maka kinerja keuangan LPD juga akan mengalami peningkatan. Begitupula sebaliknya, jika semakin buruk penerapan variabel transparancy, accountability, responsibility, independency, dan fairness dalam pengelolaan sebuah LPD maka kinerja keuangan LPD juga akan mengalami penurunan.

Hasil penelitian lain yang sejalan dengan hasil penelitian ini yakni penelitian yang dilakukan oleh Kuddy (2017) yang menemukan bahwa a) Penelitian ini 
membuktikan bahwa pengetahuan anggota dewan tentang anggaran berpengaruh terhadap pengawasan APBD. b) Interaksi antara pengetahuan dewan tentang anggaran dengan gaya kepemimpinan juga berpengaruh terhadap pengawasan APBD.

c) Hasil penelitian ini tidak dapat membuktikan bahwa interaksi antara pengetahuan dewan tentang anggaran dengan akuntabilitas publik berpengaruh terhadap pengawasan APBD. d) Interaksi antara pengetahuan dewan tentang anggaran dengan partisipasi masyarakat berpengaruh terhadap pengawasan APBD. e) Interaksi antara pengetahuan dewan tentang penganggaran dengan transparansi kebijakan publik tidak berpengaruh terhadap pengawasan APBD.

\section{KESIMPULAN}

Jawaban responden dalam studi ini menjelaskan bahwa transparansi dan akuntablitas keuangan sekolah di Kabupaten Keerom berada pada kategori tinggi. Juga motivasi mengajar guru berada pada kategori tinggi. Ada pengaruh positif variabel transparansi terhadap motivasi guru, dan hubungan ini secara statistik signifikan. Juga ada pengaruh positif variabel akuntabilitas terhadap motivasi guru, namun secara statistik hubungan ini signifikan.

Studi ini ingin merekomendasikan kepada peneliti lain dalam topik yang sama. Pertama, menambahkan pengumpulan data dengan wawancara mendalam (indepth interview) untuk mengkaji mengungkapkan fenomena yang belum terungkap dalam penelitian ini. Kedua, penambahan variasi sampel, bukan hanya dari guru, tetapi juga pengawas, pegawai dan komite sekolah.

\section{DAFTAR PUSTAKA}

Adlyana, Y. (2016). Kurikulum Pendidikan Dan Konsep Kerja (Studi Mengenai Kurikulum Sekolah Dasar dalam Menggambarkan Konsep Kerja pada Anak di Kecamatan Pajangan, Bantul, Yogyakarta). Universitas Gadjah Mada.

Andreana, M. O. C., \& Wirajaya, I. G. A. (2018). Pengaruh Transparancy, Accountability, Responsibility, Independency, dan Fairness Pada Kinerja 
Keuangan Lembaga Perkreditan Desa. E-Jurnal Akuntansi, 1305-1331.

Arifani, C., Salle, A., \& Rante, A. (2018). Pengaruh Akuntabilitas, Transparansi Dan Pengawasan Terhadap Kinerja Anggaran Berbasis Value For Money. Jurnal Akuntansi Dan Keuangan Daerah, 13(1), 68-82.

boy, D. (2009). Analisis Pengaruh Akuntabilitas Dan Transparansi Pengelolaan Anggaran Pendapatan Dan Belanja sekolah (APBS) Terhadap Partisipasi Orang Tua Murid. Akuntansi Pemerintahan Pasca Sarjana Universitas Gunadarma, 7987.

Dharma, S. (2010). Australian Dairy: Financial Performance of Australian Dairy Farms, 2007-08 to 2009-10. ABARE.

Dwiyanto, A. (2006). Mewujudkan Good Governance Melalui Pelayanan Publik. Gajah. Mada Press, Yogyakarta.

Engkay Karweti. (2010). Pengaruh Kemampuan Manajerial Kepala Sekolah Dan Faktor Yang Mempengaruhi Motivasi Kerja Terhadap Kinerja Guru Slb Di Kabupaten Subang. Jurnal Penelitaian Peendidikan, Pe(2), 77-89.

Indonesia, R. (2003). Undang-undang Republik Indonesia nomor 20 tahun 2003 tentang sistem pendidikan nasional. Jakarta: Pemerintah Republik Indonesia.

Krina, L. L. (2003). Indikator \& Alat Ukur Prinsip Akuntabilitas, Transparansi \& Partisipasi, Sekretariat Good Public Governance Badan Perencanaan Pembangunan Nasional. Jakarta.

Kuddy, A. L. (2017). Type of Leaderships, Accountability, Public Participation and Transparency of Public Policy as moderation to Degree of Legislative's Members Budgeting Knowledge in Controlling the Regional Budget (APBD). Jurnal Kajian Ekonomi Dan Keuangan Daerah, 1(3).

Mahsun, M. (2006). Pengukuran Kinerja Sektor Publik Edisi Pertama. Cetakan Pertama. Yogyakarta: Penerbit Fakultas Ekonomi Universitas Gadjah Mada.

Mardiasmo. (2004). Perwujudan Transparansi Dan Akuntabilitas Publik Melalui Akuntansi Sektor. Jurnal Akuntansi Pemerintahan.

Muro-Abad, J. I., Gomes, E. A., Cancio, O. N., \& De Araujo, E. F. (2001). Genetic Analysis Of Eucalyptus Urophylla And E. Grandis Clones Selected In Commercial Crops From The Brazilian Amazon By RAPD Markers. Silvae Genética, 50(5-6), 177-180.

Nasional, D. P. (2009). Standar Pendidikan Anak Usia Dini. Jakarta: Depdiknas.

Rohani. (2008). Pengelolaan Pengajaran. Jakarta: Rineka Cipta.

Sabarno, H. (2007). Memandu Otonomi Daerah menjaga Kesatuan Bangsa: Untaian Pemikiran Otonomi Daerah. Sinar Grafika.

Shafratunnisa, F. (2015). Penerapan prinsip transparansi dan akuntabilitas dalam pengelolaan keuangan kepada stakeholders di sd islam binakheir.

Slamet Riyadi. (2011). Pengaruh Kompensasi Finansial , Gaya Kepemimpinan , dan Motivasi Kerja. Jurnal Manajemen Dan Kewirausahaaan, Vol. 13 , 40-45. https://doi.org/10.9744/jmk.13.1.40-45

Sutama. (2006). Pengembangan Sumberdaya Manusia Guru Pendidikan Dasar Dan Menengah Di Era Otonomi Daerah (Sebuah Tinjauan Teoritis Tentang Inovasi Pengembangan SDM). Jurnal Manajemen Pendidikan (Journal Of Education Managemen), 1.

Syah, M. (1995). Psikologi pendidikan suatu pendekatan baru. Bandung: Remaja Rosdakarya.

Tabrani. (1989). Pendekatan Dalam Proses Belajar Mengajar. Remadja Karya CV.

undang-undang RI No.14 Tahun 2005. (2005). Undang-Undang Republik Indonesia Nomor 14 Tahun 2005 Tentang Guru Dan Dosen. Undang-Undang Republik Indonesia Nomor 14 Tahun 2005 Tentang Guru Dan Dosen.

Utama, D. A., \& Setiyani, R. (2014). Pengaruh Transparansi, Akuntabilitas, Dan 
Responsibilitas Pengelolaan Keuangan Sekolah Terhadap Kinerja Guru. Dinamika Pendidikan, 9(2).

Yuliyani, H. (2010). Hubungan Antara Pengalaman Mengajar Dan Motivasi Mengajar Dengan Kompetensi Guru Pendidikan Pancasila Dan Kewarganegaraan Di Sekolah Menengah Pertama Di Kabupaten Karanganyar, 1-81. https://doi.org/10.1016/s0022-5320(72)80046-7 